\title{
SWOT Analysis of Indonesian Tax Administration Innovation in the Digitalization Era
}

\author{
Notika Rahmi ${ }^{1}$, Damith Gangodawilage ${ }^{2}$ \\ ${ }^{1}$ Institut Ilmu Sosial dan Manajemen STIAMI \\ ${ }^{2}$ Sri Lanka Institute of Taxation, Sri Lanka \\ Correspondent: notika.rahmi@,gmail.com ${ }^{1}$
}

$\begin{array}{ll}\text { Received } & \text { : August 26, } 2021 \\ \text { Accepted } & \text { : January 15, } 2022 \\ \text { Published } & \text { : January 31, } 2022\end{array}$

Citation: Rahmi, N., Gangodawilage, D (2022). SWOT Analysis of Indonesian Tax Administration Innovation in the Digitalization Era. Ilomata International Journal of Tax \& Accounting.3(1), 22-34. https://doi.org/10.52728/ijtc.v4i1.423

\begin{abstract}
With the innovation in tax administration services in Indonesia in the digitalization era, it is hoped that it can increase taxpayer compliance and is expected to continuously have a positive effect on state revenues. The purpose of this study is to analyze what are the strengths, weaknesses, opportunities and threats in the implementation of tax administration innovations in Indonesia in the Digitalization Era. The research method used is qualitative with a descriptive approach. The results of the study show that the strengths and opportunities that can be utilized are the reliability of human resources that have been fulfilled, as evidenced by the satisfaction index of DGT service users reaching a scale of 4.1. Technology that can still be developed is also a strength. The high participation of taxpayers in following the innovation policy of tax administration is a very big opportunity with the number of manual SPT users recorded which has decreased by $88.8 \%$ in the last five years. Weaknesses and threats encountered are the lack of maintenance on the server where server downs often occur during the deadline for reporting SPT. Taxpayers also admitted that they had not fully received directions on how to operate the new tax administration system. Taxpayers need to adapt to the digitalization that is being carried out. So it is the government's duty to pay extra attention to the understanding of taxpayers in the application of the digital tax administration system.
\end{abstract}

Keywords: SWOT Analysis, Tax Administration Innovation, Digitalization Era.

\section{INTRODUCTION}

The rapid development of technology makes all aspects must follow the flow and innovate so as not to be left behind. Technological developments have also changed global trends, ranging from an all-digital administration system to public services that are usually provided directly and can be enjoyed online through a mobile phone screen (Kudrle, 2021). In some developed countries and even developing countries, public sector organizations are still lagging behind and have not been able to make maximum use of technology to gain profits, especially in providing services to the public (Mergel et al., 2019). The tax authority is one part that plays an important role in the public

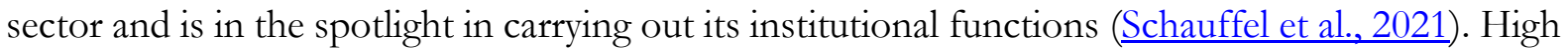


expectations of public services in the taxation sector are expected by the community so that taxation also utilizes technology in providing services (Cheba et al., 2021). The technological developments referred to include digital payments, data-based currencies and technology infrastructure in effective and efficient services. Tax administration is the backbone in fulfilling taxation rights and obligations in order to run a legal business in each country. The role of the public sector in the field of tax administration must be able to adapt to technological innovations that have developed in the midst of thesector private (Bai et al., 2021)

In the research conducted by (Barnay et al., 2018) related to tax authorities, from several countries in the world (21 countries) there are four important things that need to be paid attention to by the public sector in the field of tax administration to be able to encourage technological innovation to be able to run the function of public services well, namely firstly on interaction with taxpayers using digital technology (Wulandari, 2021). In this study, it was explained that the tax authority could create a channel digitalin responding to taxpayers' requests for tax services. There is easy access to public services in the field of taxation. The function of digitizing on a large scale can also be carried out by integrating taxpayer monitoring in the form of an integrated accounting management system architecture. With this technology function, data becomes centralized, workflows can be reviewed digitally in each department, starting from the audit process, tax collection, restitution process and others (Syafitri, 2018). The technology function can also help in terms of service customer, analyze tax non-compliance to be able to resolve tax collection issues. The second thing is data analysis, several tax authorities have carried out further data analysis functions in terms of mapping the importance of taxpayer compliance levels so that tax audit priorities can be formed. Several countries have also innovated by changing the way of conducting audits, collecting taxes and creating a monitoring system for taxpayer compliance. Several developed countries in Europe have implemented the tax innovation function by mapping the level of taxpayer liquidity, so that they were able to increase tax revenues by US $\$ 800$ million and reduce operating costs by around US\$ 8 million (Barnay et al., 2018).

The third thing that needs to be paid attention to by the public sector in the field of tax administration is to be able to encourage technological innovation to be able to carry out the function of public services properly, namely procession automation. This includes the use of efiling, data checking automation, reminders, and other automation (Abdelfattah \& Aboud, 2020). Currently the public sector is in the stage of reorganization in the digitalization process. They carry out the process of recruiting and training employees to be able to adapt to the use of digital technology in their business processes (Batrancea et al., 2019). But what happened was a shift in the function of the workforce by digitizing the entire business process without any help from humans. Several Asian countries are currently implementing innovation by doing automation. One example is the launch of an online machine to help speed up the digital justice process. This is to speed up the dispute process which usually takes a long time and is very inefficient (Adi, 2020; Rusli, 2019). Next, the fourth is talent management or human resource management. Most current tax authorities are still inadequate in terms of technology to understand the factors that influence HR excellence so that it has an impact on organizational health in assessing organizational governance. According to research (Barnay et al., 2018) as many as $60 \%$ of public organizations fail to carry out the transformation process due to the absence of clear directions and goals (McKinsey and Company, 2017). 
In general, net tax revenues in 2020 reached Rp. 1,072.11 trillion or 89.43 percent of the 2020 State Budget target of Rp. 1,198.82 trillion. The realization of the tax revenue grew negative 19.55 percent compared to the realization in 2019, slower than the growth in 2019 which was still able to grow slightly at 1.47 percent. The government has made two adjustments to the tax revenue target in the 2020 State Budget in response to the impact of the Covid-19 pandemic. The last adjustment was made through Presidential Decree No. 72 of 2020, the tax revenue target was adjusted to Rp1,198.82 trillion. However, until the end of 2020 the realization of revenue was only able to reach 89.43 percent of the target.

Table 1

\section{Performance of 2016-2020 Tax Revenue Realization}

\begin{tabular}{|c|c|c|c|c|c|c|}
\hline \multirow{9}{*}{ 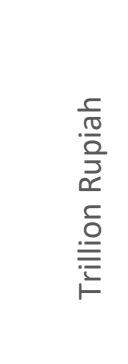 } & $1,400.00$ & & & & & \\
\hline & $1,200.00$ & & & & & \\
\hline & $1,000.00$ & & & & & \\
\hline & 800.00 & & & & & \\
\hline & 600.00 & & & & & \\
\hline & 400.00 & & & & & \\
\hline & 200.00 & & & & & \\
\hline & 0.00 & & & & & \\
\hline & & 2016 & 2017 & 2018 & 2019 & 2020 \\
\hline With Oi & me Tax & $1,105.97$ & $1,151.03$ & $1,313.32$ & $1,332.66$ & $1,072.12$ \\
\hline Withou & Income Tax & $1,069.87$ & $1,100.71$ & $1,248.61$ & $1,273.49$ & $1,039.08$ \\
\hline
\end{tabular}

Source: Financial Report of DGT 2016-2020

The government has also focused on developing by utilizing technology, one of which is by accelerating digital transformation in government administration. The strategic activities carried out are providing base transceiver stations (BTS) in 3T villages, providing internet access, building national data centers, digital literacy, digital transformation of strategic sectors, digital technopreneurs, controlling the implementation of electronic systems, and supporting digitalization of education such as procurement of ICT tools. and learning media (Kementerian Keuangan, 2021). The Directorate General of Taxes is currently implementing tax reforms to provide optimal state revenue. One of the efforts made is by using a digital system in tax transactions (Anggraini et al., 2021; Sulistyowati et al., 2020). Tax administration innovations that are currently being implemented are the provision of services in NPWP registration (eregistration), tax payment services (e-billing), and services in tax reporting (e-filing, e-form, einvoice), all of which have been can be done electronically (Hasanah \& Indriani, 2013; Lintang et al., 2017).

With the innovation in tax administration services, taxpayers are given convenience, get cost efficiency and get real time in terms of carrying out tax obligations which include registration, payment and tax reporting (Faúndez-Ugalde et al., 2020; Olivares, 2018). This ease of access to tax administration is expected to increase taxpayer compliance and is of course expected to have a positive effect on state revenues (Bahmid \& Wahyudi, 2018). In this study, the author will find out what are the strengths, weaknesses, opportunities and threats in the implementation of tax administration innovations in Indonesia in the Digitalization Era. 


\section{METHOD}

This study uses a qualitative method, which according to Strauss and Cobin, qualitative is a type of research that obtains findings whose results cannot be obtained by statistical means (Ghozali, 2016; Sugiyono, 2019). The type of research is descriptive research, namely research that has the aim of describing, describing facts, properties and combining the phenomena to be studied including activities, attitudes, views and ongoing plots and the influence of a phenomenon or to determine the frequency distribution of a symptom that is mutually related (Silaen \& Widiyono, 2013). The concept in this study is to analyze the strengths of tax administration innovation activities in Indonesia, analyze the weaknesses and opportunities and challenges in implementing tax administration innovations in Indonesia. Data collection techniques were carried out starting from making observations at the Directorate General of Taxes of the Republic of Indonesia, followed by collecting data relating to state revenues and legal products produced during the tax administration innovation process and then conducting interviews with resource persons from various groups, starting from representatives tax officers, taxpayers to academics to strengthen the information obtained.

\section{RESULT AND DISCUSSION}

Era of digitalization has been one of the triggers for Volume III Tax Reform in Indonesia, which began in 2016. In addition to constantly updating tax policies, the tax administration system also participates in reforms along with the times and changing administrative dynamics. The government has planned an agenda for the Reform of the Tax Administration Core System (PSIAP), but in 2020 the COVID-19 pandemic hit the entire country, including Indonesia. Various impacts ranging from health to the economy must be faced. The very fast transmission of the virus makes tax services, which are still through face-to-face visits, now impossible. This has the effect of decreasing tax returns (SPT). Although tax reporting facilities have been provided through efilling and e-forms, there are still many taxpayers who are still accustomed to reporting taxes by getting direct face-to-face guidance from tax officials. The use of digital technology is not only focused on services, but also on supervision of taxpayers. This is done to make the tax administration information system easy, reliable, accurate, integrated and optimize services and supervision.

Digitization carried out by the Directorate General of Taxes starts from taxpayer registration services to online payments and reporting with the following details:

1. E-Registration. Is a taxpayer registration service that is done online. Regarding the registration procedure, the taxpayer identification number and/or inauguration of taxable entrepreneurs and changes to the data of taxpayers and/or taxable entrepreneurs with the system eregistration regulated in the regulation of the director general of taxes number 24/PJ/2009 as last amended by Regulation Director General of Taxes number PER-02/PJ/2018 concerning the second amendment to the regulation of the director general of taxes number PER20/PJ/2013 concerning procedures for registration and granting of taxpayer identification numbers, business reporting and inauguration of taxable entrepreneurs, deletion of taxpayer identification numbers, and revocation of the inauguration of taxable entrepreneurs as well as changes to data and transfer of taxpayers.

2. E-billing. It is an electronic tax payment service system where before the existence of e-billing, taxpayers are required to come to the designated bank to make payments and obtain proof of payment. Regarding the procedure for implementing the trial implementation of the electronic 
tax payment system (billing system) in the state revenue module system, it is regulated in the Regulation of the Director General of Taxes number PER-47/PJ/2011 as last amended by the regulation of the director general of taxes number PER-05/PJ /2017 concerning electronic tax payments.

3. E-filling. It is an electronic tax reporting service system. Previously, tax reporting was carried out by directly visiting the Domicile Tax Service Office following office hours by bringing the filled SPT form. But now tax reporting can be done anywhere and anytime. Regarding the procedure for submitting annual notification letters for individual taxpayers who use forms 1770 S or 1770SS by e-filling through the website of the directorate general of taxation (www.pajak.go.id) it is regulated in the Regulation of the Director General of Taxes number PER-39/PJ/2011 as the latest amended by the director general of tax regulation number PER1/PJ/2014 regarding the procedure for submitting annual notification letters for individual taxpayers who use forms 1770 S or 1770 SS by e-filling through the website of the directorate general of taxes (www.pajak.go.id). Furthermore, the director general of taxes issued an eform in 2017 which is included in the e-filling service. The e-form service has almost the same function as e-filling. In this service, taxpayers download the annual SPT formula first and can fill it out offline and then upload it when it is finished via the previous page.

4. E-faktur, is an electronic system application provided by the DGT to make it easier for Taxable Entrepreneurs to make tax invoices in a uniform format and e-invoices provide services for making tax invoices electronically. This e-invoice is expected to save processing time. Before the existence of e-invoices, the creation of tax invoices manually and had a big chance of not being uniform in the format of tax invoices. The new e-faktur application was launched in 2014 where the procedure for making and reporting tax invoices in electronic form is regulated in the director general of tax regulation number PER-16/PJ/2014 as last amended by PER-31/PJ/2017.

In July 2021, the Directorate General of Taxes has also introduced four new analytical data-based applications to support supervision, namely Compliance Risk Management (CRM)Function Transfer Pricing (TP), Ability to Pay (ATP), Smartweb, and Dashboard Office Taxpayer (WP). Madya Tax Service (KPP) (Redaksi DDTCNews, 2021). The use of these technologies has been in line with trends in several countries. About $75 \%$ of the authorities have plans to continue working to move field inspections to digital. Nearly $60 \%$ of the authorities are expanding the application of innovative technology in calculating compliance levels and identifying when there is fraud or fraud in taxation (Organization for Economic Cooperation and Development, 2021).

\section{SWOT Analysis on Tax Administration Innovations in Indonesia}

SWOT analysis is a tool used to analyze companies from internal and external perspectives to produce strategies for the company (Cheng et al., 2021). SWOT Consists of Strengths, Weaknesses, Opportunities and Threats (Zhou et al., 2019). In this study, the company in question is the government agency of the Director General of Taxes as a policy maker (Jannah et al., 2017). Every organization has strengths and weaknesses in the functional areas of the business that can be used as the basis for the goals and strategy setting of an organization (Erawati \& Wance, 2021). The author has conducted interviews with various parties, namely the Head of the section on counseling guidance and document management at the Directorate General of Taxes, Central Jakarta, interviews were also conducted with taxpayers who utilize tax administration innovation facilities as well as academics, tax lecturers at the STIAMI Institute of Social Sciences and 
Management. The following is a SWOT analysis on the implementation of Tax Administration Innovations in Indonesia in the digitalization era.

\section{a. Strength}

Consists of internal factors that support the company in achieving a goal. These supporting factors can be in the form of resources, expertise or other advantages that may be obtained from financial sources, market advantages, image or good relations between policy makers and those who use the policy. An efficient tax administration system can change the basic process of taxpayer compliance. However, of course, human resources are still needed to be relied on in managing the Tax Administration System. With the increasing number of taxpayers, the use of technology in the tax administration system is a solution to simplify administrative complexities. So that later the tax authorities can reduce the need for human resources in managing the implemented system (Surya, 2020). Every year the number of taxpayers has increased, although not significantly, but is increasing. If the tax administration process is still done manually, of course this must be balanced with increased Human Resources to assist registered taxpayers in fulfilling their tax obligations. However, because the current tax administration process has been adapted to the digital era, it is not something to worry about if the number of taxpayers continues to increase. On the contrary, it will be a great opportunity for state revenue from the tax sector. The following is data on the growth of taxpayers from 2016 to 2021 :

Table 2

Number of Registered Taxpayers 2016-2021

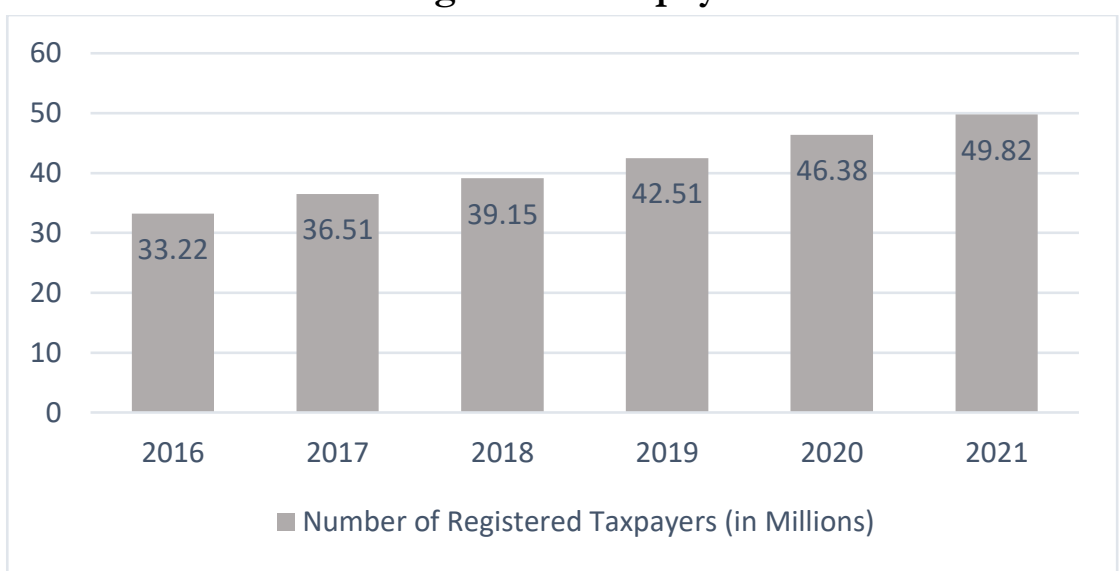

Source: Ministry of Finance of the Republic of Indonesia, 2021

In the performance report of the Directorate General of Taxes for 2020, it was recorded that in Indonesia there were 46,305 DGT employees spread over 595 DGT offices. With details as many as 8,182 employees in the Sumatran region, 29,382 employees on the island of Java, 2,958 employees in Kalimantan, 2,850 employees in Sulawesi and North Maluku, 1,997 employees in Bali and Nusa Tenggara and 852 employees in the Papua and Maluku regions. It was explained that the DGT service user satisfaction index had exceeded the target of 4.1 from the target of 4 points (maximum scale of 5). If the percentage is achieved, the satisfaction index is $102.50 \%$. The Directorate General of Taxes has also claimed that the achievement of the quality index for managing information and communication technology (ICT) systems is $118.83 \%$ (Direktorat Jenderal Pajak, 2020). 
The International Monetary Fund, together with The Organization for Economic Co-operation and Development (OECD), the Intra-Eurpean Organization of Tax Administrations (IOTA) and the Asian Development Bank (ADB) have conducted a joint survey called the International Survey on Revenue Administration (ISORA). The types of technology that are currently developing and are used as aspects of a survey of innovative technology developments in the application of digital tax administration.

1. Blockechain. A digital data storage system consisting of transaction record data or data spread over ainternet network multiserver. This data structure can be disseminated and managed globally at the same time of course with guaranteed information security. This technology has been widely used by banking, logistics, e-commerce companies, and including in the world of taxation. This will make it easier for taxpayers to pay taxes and can support the transparency of tax transactions in Indonesia.

2. Robotic Process Automation (RPA). Technology that offers new ways of doing data analysis, risk management and can help improve performance efficiency. Many companies have utilized this technology in their work processes. Work processes that are done manually and repeatedly are no longer effective and take up a lot of time.

3. Artificial Intelligence. The application of artificial intelligence technology can help examine large amounts of data and make it possible to carry out surveillance in the identification of suspicious transactions more practically.

4. Chatbots. Technology in the form of conversation products using technology Artificial Intelligence (AI). This technology can connect between parties with the resulting discussion easy to learn and understand by users.

5. Identification biometric. Technology to achieve transparency and accountability in financial transactions. Information can include fingerprint recording, iris scanning, and voice and face recognition. This technology has been applied in India in the field of taxation.

The strength of the internal factors in this innovation is the presence of adequate Human Resources in terms of quantity and quality in carrying out administrative digitization. Good service has also been provided by the Tax authorities as a tax officer where this is evidenced by the taxpayer's statement saying that the innovations made are good and the services provided are good enough and the policies made are right on target. Taxpayers have also benefited from the innovation of tax administration, namely paying taxes is easier, there is no need to queue and the process is not difficult. Innovation in the field of taxation can still be developed with a wider scope.

As information obtained by Bintang Perdana Putra as one of the delegates from DDTC at the International Tax conference in Mumbai. The proposed new idea related to the application of tax administration and regulation systems in the digital era was presented by the Director of Global Tax Policy Center at the Institute for Austrian and International Tax Law, WU (Vienna University of Economics and Business). Mr. Jeffrey Ownes stated that the traditional compliance model requires The completion time is quite long because various administrative processes must be passed. The process starts from recording accounting data, analyzing tax costs, filling out tax reporting forms, submitting tax reporting forms to waiting for the audit process by the tax authorities. Basically the process can be shortened by digital compliance model (Redaksi DDTCNews, 2019). 


\section{b. Weakness}

Includes internal factors that can hinder the company in achieving its goals. Inhibiting factors can be in the form of inadequate facilities, lack of funding sources, lack of ability to manage, inadequate marketing skills and poor company image. In the results of interviews that have been conducted, representatives from the tax authorities stated that they did not find any weaknesses in conducting tax administration innovations. This means that from facilities, sources of funds to the ability to manage and expertise in introducing innovations to the tax administration system, they are adequate. However, the author found different things in interviews with academics, he said that the weakness encountered was in the management of technology. In its use, several times the server was down so that it interfered with tax administration activities. This usually happens with the use of e-filling at crucial times, such as the deadline for reporting the Annual SPT.

We also found weaknesses in socialization, which means in terms of introducing innovations made to taxpayers. The rapid development of technology must be accompanied by the rapid acceptance of all new information, especially related to digitalization. But unfortunately there are still many taxpayers who actually have difficulty in accessing these digital-based services. They are used to and comfortable with manual service so it is quite difficult to adapt to new things. Of course, this is the task of the tax authorities to be able to convey properly the procedures for applying programs related to digital innovation in tax administration. The difficulty of taxpayers adapting to this alldigital change is also supported by data on the level of taxpayer compliance which is unstable every year. The following is data on taxpayer compliance from 2016 to 2020:

Table 3

Taxpayer Compliance Ratio Income Tax

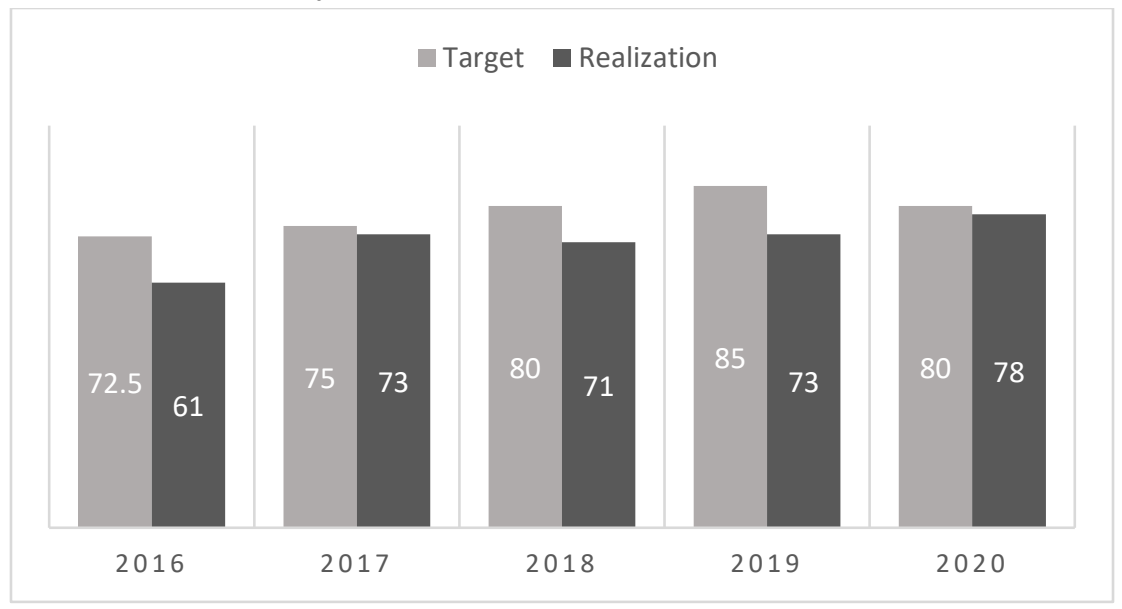

Source: Ministry of Finance, 2020

From the data above, it can be seen that from 2016 to 2020, the level of taxpayer compliance has never reached the target set. Although quantitatively the realization of taxpayer compliance in the last three years has increased although not too much, namely in 2018 the realization was $71 \%$ then increased by $2 \%$ from the previous year to $73 \%$ in 2019. Furthermore, in 2020 there was an increase of $5 \%$ from last year to $78 \%$. With the various innovations in the tax administration system in Indonesia, it is certainly expected to be able to encourage taxpayer compliance. This is because digitalization can provide convenience to taxpayers. But in reality, taxpayers also need to make adjustments and adaptations to the digitalization that is being carried out. So it is the government's duty to pay extra attention to the understanding of taxpayers in the application of the digital tax administration system. 


\section{c. Opportunity}

As external factors that support the company in achieving its goals. It can be in the form of changes in policy, technology, competition and the development of relations between policy makers and policy users. By utilizing digital technology in the tax administration system, it can help reduce or even eliminate human errors, operations backend in services to taxpayers, even with this digitalization it is no longer necessary to have a meeting between taxpayers and tax officers directly, considering the current covid virus. -19 is still ongoing. If it is necessary to have a meeting between the taxpayer and the tax officer, this can be done online. To be able to achieve this, the tax authorities must continue to make changes and organizational transformation in a sustainable manner by utilizing technology. In research conducted by (Syafitri, 2018) shows that with the implementation of tax administration digitization services, the increase in taxpayer compliance with digitalization service users is proportional to the increase in taxpayer compliance. And the increase in taxpayer compliance ratio is proportional to tax revenue. The same thing is proven in research conducted (Wulandari, 2021) showing a positive influence from the implementation of efilling and e-invoicing on taxpayer compliance.

This proves that there are more opportunities for tax revenue if the taxpayer has been able to adapt well to the digitalization of tax administration. Taxpayers who have understood and can take advantage of tax administration innovations tend to be more obedient to tax provisions. This is also the hope of tax officials, with the convenience of tax services, tax compliance and revenue are also expected to increase. Especially during the current pandemic, digitizing the tax administration system can help reduce the occurrence of virus transmission due to face-to-face meetings that were previously held when they wanted to report SPT. Volunteering in paying taxes because of the convenience was also conveyed by the taxpayers we interviewed. He said that the easy process of tax administration gives pleasure so that taxpayers are not burdened in the administrative process. The following is a summary of tax administration activities before and after the innovation in the tax administration system in Indonesia:

Table 4

Tax Services Before and After Tax Administration Innovation

\begin{tabular}{|l|l|l|c|}
\hline \multicolumn{1}{|c|}{ Types of Services } & Before Innovation & After Innovation & $\begin{array}{c}\text { Product \& Legal } \\
\text { Basis }\end{array}$ \\
\hline Making NPWP & $\begin{array}{l}\text { Come directly to the } \\
\text { tax office }\end{array}$ & $\begin{array}{l}\text { Can be accessed } \\
\text { online }\end{array}$ & $\begin{array}{c}\text { E-Registration } \\
\text { PER-02/PJ/2018 }\end{array}$ \\
\hline Tax Payments & $\begin{array}{l}\text { Come directly to the } \\
\text { Perception Bank }\end{array}$ & $\begin{array}{l}\text { Can be accessed } \\
\text { online }\end{array}$ & $\begin{array}{c}\text { E-Billing } \\
\text { PER-05/PJ/2017 }\end{array}$ \\
\hline Tax Reporting & $\begin{array}{l}\text { Come directly to the } \\
\text { tax office }\end{array}$ & $\begin{array}{l}\text { Can be accessed } \\
\text { online }\end{array}$ & $\begin{array}{c}\text { E-Filling } \\
\text { PER-1/PJ/2014 }\end{array}$ \\
\hline Tax Invoice Making & $\begin{array}{l}\text { Manual. Potential } \\
\text { for misuse of tax } \\
\text { invoice }\end{array}$ & $\begin{array}{l}\text { Automatic. Cannot } \\
\text { be misused }\end{array}$ & $\begin{array}{r}\text { E-Faktur } \\
\text { PER-31/PJ/2017 }\end{array}$ \\
\hline
\end{tabular}

Source: Processed by Author, 2022

It can be concluded that with the digitalization of the tax administration system, the tax service process becomes easier and more effective and efficient both in terms of time, effort and cost. Besides being able to improve service performance, digitizing tax administration can also solve tax problems at the local government level because currently there are still many fraudulent practices 
and tax leakages and the weak mapping of tax potential. With digitalization, local governments can oversee various tax activities, as well as provide fast service. Currently, the benefits of innovation in the tax administration system have been felt. Gradually, taxpayers have taken advantage of the facilities provided as follows:

Table 5

Development of Submission of E-Filling, E-Form, E-SPT and Manual

\begin{tabular}{|c|r|r|r|r|}
\hline $\begin{array}{c}\text { Year SPT } \\
\text { Received }\end{array}$ & e-Filling & e-Form & e-SPT & SPT Manual \\
\hline 2016 & 8.817 .614 & - & 8.389 .730 & 17.919 .891 \\
\hline 2017 & 10.875 .117 & 103.650 & 8.738 .750 & 15.179 .738 \\
\hline 2018 & 17.095 .207 & 344.346 & 4.309 .794 & 3.953 .281 \\
\hline 2019 & 22.083 .186 & 913.040 & 1.552 .185 & 1.859 .495 \\
\hline 2020 & 22.003 .662 & 995.243 & 1.346 .463 & 1.591 .422 \\
\hline
\end{tabular}

Source: Directorate of Tax Data and Information, 2020

From the data above, it can be seen that the use of manual tax returns from 2016 to 2020 has decreased, while the use of e-filing and e-forms has always increased every year. This is indeed the main goal of the Directorate General of Taxes in innovating tax administration in Indonesia.

\section{d. Threat}

External factors that hinder the company in achieving its objectives can be a new competitor, the market growth is slowing, technological changes, policy changes and increased bargaining power than the policy makers and policy. From all the conveniences and benefits that come from digitizing the tax administration system, there are also threats that must be faced, such as the opportunity for digital crimes (cybercrimes). Lack of understanding and competence in the field of digital technology and challenges during the transition period due to changes in the tax administration system (Redaksi DDTCNews, 2019). The tax authorities also fear for the damage to the server if it is not in the maintanance of good programs that have been run. The same thing was conveyed by representatives of academics who were interviewed by the author that it was necessary to gradually improve the system to reduce the chance of damage and even damage to the system by irresponsible people. As previously explained, taxpayers also experience difficulties in accessing digitization programs. With frequent changes to the system, taxpayers must adapt again to existing algorithms. The latest features that are presented to tax officers are certainly an achievement, but for taxpayers it is a threat, especially for taxpayers who are not familiar with everything technology-based.

Technological developments must also be balanced with knowledge about technology itself. In this case, information is not only needed by human resources who are in the environment of policy makers, but information is also needed by taxpayers as policy users. Because the policies that have been made in practice will be used by taxpayers. It is a task that cannot be ignored by the government to continue to pay attention to the knowledge of taxpayers regarding the use of administrative system services in the digital era. The more taxpayers who understand the use of digital administration systems, the greater the potential to be able to improve taxpayer compliance. Increased taxpayer compliance will also provide an increase in tax revenue. 


\section{CONCLUSION}

Innovating the tax administration system in the digital era is a must. The acceleration of technological change must also be balanced with the ability to adapt, both by policy makers and policy users. Tax administration innovations carried out in Indonesia have been running well. Strengths and opportunities that can be exploited are in the form of adequate Human Resources to accompany the increasing number of registered taxpayers. The reliability of HR has also been met as evidenced by the satisfaction index of DGT service users of 4.1 from the target of 4 points (maximum scale of 5). Technology that can still be developed is also a force for tax administration innovation. The high participation of taxpayers in following the innovation policy of tax administration is a very big opportunity with the number of manual SPT users recorded which has decreased by $88.8 \%$ in the last five years. Weaknesses and threats were encountered, namely from the internal side of the tax office, they felt that there were no weaknesses, but according to academics and taxpayers they found that there was still a lack of maintenance on the server where often occurred server downs during the SPT reporting deadline. Taxpayers also admitted that they had not fully received directions on how to operate the new tax administration system. Taxpayers need to adapt to the digitalization that is being carried out. So it is the government's duty to pay extra attention to the understanding of taxpayers in the application of the digital tax administration system. The more taxpayers who understand the use of digital administration systems, the greater the potential to be able to improve taxpayer compliance. Increased taxpayer compliance will also provide an increase in tax revenue.

\section{REFERENCE}

Abdelfattah, T., \& Aboud, A. (2020). Tax avoidance, corporate governance, and corporate social responsibility: The case of the Egyptian capital market. Joumal of International Accounting, Auditing and Taxation, 38, 100304. https://doi.org/10.1016/j.intaccaudtax.2020.100304

Adi, I. K. Y. (2020). Efektifitas E-Filing Terhadap Peningkatan Kepatuhan Wajib Pajak Orang Pribadi dengan Tingkat Keamanan dan Kerahasiaan Sebagai Variabel Moderasi (Studi Empiris Pada Kantor Pelayanan Pajak Pratama Badung Utara). Journal of Applied Management and Accounting Science, 2(1), 53-66. https://doi.org/10.51713/jamas.v2i1.26

Anggraini, D., Damayanti, \& Nurmala. (2021). Strategi Pengembangan Bisnis dengan Pemanfaatan Insentif Pajak dan Digitalisasi UMKM di Era New Normal. Jurnal Kajian Agribisnis Dwijen Agro, 11(1), 24-32. http://ejournal.undwi.ac.id/index.php/dwijenagro/article/view/1081

Bahmid, N. S., \& Wahyudi, H. (2018). Pengaruh Pemungutan Pajak Hotel dan Pajak Hiburan Terhadap Peningkatan Pendapatan Asli Daerah Kota Medan. Jurnal Riset Akuntansi Dan Bisnis, 18(1), 14-26. https://doi.org/10.30596/jrab.v18i1.2046

Bai, C., Quayson, M., \& Sarkis, J. (2021). COVID-19 pandemic digitization lessons for sustainable development of micro-and small- enterprises. Sustainable Production and Consumption, 27, 1989-2001. https://doi.org/10.1016/j.spc.2021.04.035

Barnay, A., Davis, J., Dimson, J., Gibbs, E., \& Korn, D. (2018). Four Innovations Reshaping Tax Administration. https://www.mckinsey.com/industries/public-and-social-sector/ourinsights/four-innovations-reshaping-tax-administration

Batrancea, L., Nichita, A., Olsen, J., Kogler, C., Kirchler, E., Hoelzl, E., Weiss, A., Torgler, B., Fooken, J., Fuller, J., Schaffner, M., Banuri, S., Hassanein, M., Alarcón-García, G., Aldemir, C., Apostol, O., Bank Weinberg, D., Batrancea, I., Belianin, A., ... Zukauskas, S. (2019). 
Trust and power as determinants of tax compliance across 44 nations. Journal of Economic Psychology, 74, 102191. https://doi.org/10.1016/j.joep.2019.102191

Cheba, K., Kiba-Janiak, M., Baraniecka, A., \& Kolakowski, T. (2021). Impact of external factors on e-commerce market in cities and its implications on environment. Sustainable Cities and Society, 72, 103032. https://doi.org/10.1016/j.scs.2021.103032

Cheng, L.-C., Chen, K., Lee, M.-C., \& Li, K.-M. (2021). User-Defined SWOT analysis - A change mining perspective on user-generated content. Information Processing \& Management, 58(5), 102613. https://doi.org/10.1016/j.ipm.2021.102613

Direktorat Jenderal Pajak. (2020). Laporan Tabunan Direktorat Jenderal Pajak Tabun 2020. https://pajak.go.id/id/laporan-tahunan-2020

Erawati, S. H., \& Wance, F. (2021). Analisis SWOT Untuk Menentukan Strategi Manajerial Perusahaan yang Efektif. Jurnal Ilmu-Ilmu Sosial INSPIRASI, 18(1), 366-376. https://doi.org/https://doi.org/10.29100/insp.v18i1.1922

Faúndez-Ugalde, A., Mellado-Silva, R., \& Aldunate-Lizana, E. (2020). Use of artificial intelligence by tax administrations: An analysis regarding taxpayers' rights in Latin American countries. Computer Law \& Security Review, 38, 105441. https://doi.org/10.1016/j.clsr.2020.105441

Ghozali, I. (2016). Aplikasi Analisis Multivariete dengan Program IBM SPSS 23 (I. Ghozali (ed.); 8th ed.). Badan Penerbit Universitas Diponegoro. http:/ / kin.perpusnas.go.id/DisplayData.aspx?pId=218217\&pRegionCode=UN11MAR\&p ClientId $=112$

Hasanah, N., \& Indriani, S. (2013). Efektifitas Pelaksanaan Self Assessment System dan Modernisasi Administrasi Pajak Terhadap Kualitas Pelayanan Pajak (Studi Kasus Pada KPP Kebon Jeruk 1). Jurnal Ilmiah W ahana Akuntansi, 8(1), 17-35. http://journal.unj.ac.id/unj/index.php/wahana-akuntansi/article/view/651

Jannah, A., Suratno, A., \& Sulistiyani, E. (2017). Strategi Peningkatan Kualitas Pelayanan Berbasis SWOT pada Kantor Pelayanan Pajak Pratama Semarang Candisari. Jurnal of Business Studies JOBS, 3(2), 195-204. https://doi.org/http://dx.doi.org/10.32497/jobs.v3i2.1482

Kementerian Keuangan. (2021). Informasi APBN 2021: Percepatan Pemulihan Ekonomi dan Penguatan Reformasi. https://www.kemenkeu.go.id/media/16835/informasi-apbn-2021.pdf

Kudrle, R. T. (2021). Moves and countermoves in the digitization challenges to international taxation. Technology in Society, 64, 101453. https://doi.org/10.1016/j.techsoc.2020.101453

Lintang, K., Kalangi, L., \& Pusung, R. (2017). Analisis Penerapan E-Faktur Pajak dalam Upaya Meningkatkan Kepatuhan Pengusaha Kena Pajak untuk Pelaporan SPT Masa PPn pada KPP Pratama Manado. Jurnal EMBA: Jurnal Riset Ekonomi, Manajemen, Bisnis Dan Akuntansi, 5(2), 2023-2032. https://doi.org/https://doi.org/10.35794/emba.v5i2.16486

McKinsey and Company. (2017). The Opportunity in Government Productivity. https://www.mckinsey.com/industries/public-and-social-sector/our-insights/theopportunity-in-government-productivityhttps://www.mckinsey.com/industries/publicand-social-sector/our-insights/the-opportunity-in-government-productivity

Mergel, I., Edelmann, N., \& Haug, N. (2019). Defining digital transformation: Results from expert interviews. Government Information Quarterly, 36(4), 101385. https://doi.org/10.1016/j.giq.2019.06.002

Olivares, B. D. (2018). Technological innovation within the Spanish tax administration and data subjects' right to access: An opportunity knocks. Computer Law \& Security Review, 34(3), 628- 
639. https://doi.org/10.1016/j.clsr.2017.11.012

Organization for Economic Cooperation and Development. (2021). Tax Administration: Digital Resilience in the Covid-19 Environment. https://www.oecd.org/tax/forum-on-taxadministration/publications-and-products/tax-administration-digital-resilience-in-thecovid-19-environment.htm

Redaksi DDTCNews. (2019). Melihat Dampak Administrasi Pajak di Era Digital. Laporan DDTC Dari India. https://news.ddtc.co.id/melihat-dampak-administrasi-pajak-di-era-digital-18069

Redaksi DDTCNews. (2021). Dibalik Digitalisasi Administrasi Pajak. Reformasi Perpajakan. https://news.ddtc.co.id/di-balik-digitalisasi-administrasi-pajak-32420

Rusli, Y. M. (2019). Pengaruh Efektivitas Penerapan E-filling dan Modernisasi Sistem Perpajakan Indonesia Terhadap Efektivitas Pemrosesan Data Perpajakan. Jurnal Akuntansi Bisnis, 12(1). https://doi.org/10.30813/jab.v12i1.1509

Schauffel, N., Schmidt, I., Peiffer, H., \& Ellwart, T. (2021). Self-concept related to information and communication technology: Scale development and validation. Computers in Human Behavior Reports, 4, 100149. https://doi.org/10.1016/j.chbr.2021.100149

Silaen, S., \& Widiyono. (2013). Metodologi Penelitian Sosial Untuk Penulisan Skripsi dan Tesis (1st ed.). In Media. https://opac.perpusnas.go.id/DetailOpac.aspx?id=992941

Sugiyono. (2019). Metode Penelitian Kuantitatif Kualitatif dan R\&D (I). Alfabeta. https://cvalfabeta.com/product/metode-penelitian-kuantitatif-kualitatif-dan-rd-mpkk/

Sulistyowati, N. W., Amah, N., \& Setyaningrum, F. (2020). The Effectiveness Application of EInvoice VAT to The Taxable Entrepreneurs in KPP Pratama Madiun. Jurnal Komunikasi Ilmiah Akuntansi Dan Perpajakan Profita, 13(3), 321-334.

https://doi.org/https://dx.doi.org/10.22441/profita.2021.v13i3.002

Surya, D. (2020, February 22). Efektivitas Penggunaan Teknologi Digital untuk Administrasi Pajak. Pajakku, Artikel Pajakku. https://www.pajakku.com/read/5ef2b5930abad75bad0c60b7/Efektivitas-PenggunaanTeknologi-Digital-untuk-Administrasi-Pajak

Syafitri, Y. (2018). Penerapan Digitalisasi Administrasi Perpajakan dalam Upaya Mengoptimalkan Penerimaan Pajak di Tiga KPP [Universitas Parahyangan]. In UNPAR Institutional Repository. http://hdl.handle.net/123456789/7064

Wulandari, D. S. (2021). Digitalisasi Sistem Administrasi Perpajakan dan Biaya Kepatuhan Pajak Terhadap Kepatuhan Wajib Pajak Orang Pribadi. Journal of Accounting Science, 5(1), 36-70. https://jas.umsida.ac.id/index.php/jas/article/view/1131

Zhou, J., He, P., Qin, Y., \& Ren, D. (2019). A selection model based on SWOT analysis for determining a suitable strategy of prefabrication implementation in rural areas. Sustainable Cities and Society, 50, 101715. https://doi.org/10.1016/j.scs.2019.101715 